\title{
A SZÁMSZERÜSÍTETT VÁROSI HŐÉRZET ÉS A PUBLIKUS HŐMÉRSÉKLET ÖSSZEHASONLÍTÁSA HŐHULLÁM IDEJÉN
}

\author{
Unger János iD, Gál Tamás \\ Szegedi Tudományegyetem, Interdiszciplináris Kiválósági Központ, \\ Éghajlattani és Tájföldrajzi Tanszék, Szeged, Egyetem u. 2. \\ e-mail: unger@geo.u-szeged.hu, tgal@geo.u-szeged.hu
}

\section{Bevezetés}

Az utóbbi évtizedekben a hőhullám (HW), mint egy termikusan terhelő időszak, egyre gyakrabban és gyakrabban kerül a figyelem középpontjába, nemcsak a szakirodalomban, hanem a médiában és ezzel párhuzamosan a köznyelvben is. Ennek ellenére nincs egy általánosan elfogadott definíciója, ugyanis az, hogy mit tekintenek HW időszaknak, az éghajlati zónánként, sőt ezen belül akár országonként is nagy változékonyságot mutat. Általánosan azt mondhatjuk, hogy egy több napos, szélsőségesen magas hőmérséklettel $(T)$ jellemzett időszakról van szó, amelyben ez a termikus anomália nem csak nappal, hanem az éjszakai órákban is jelentkezik (pl. Robinson, 2001; Frich et al. 2002; Meehl \& Tebaldi 2004; Pongrácz et al., 2013; McGregor et al., 2015; Hintz et al., 2018).

Egy ilyen HW időszak alapvetően meteorológiai jelenség, de fontosságát a társadalomra tett hatása indokolja: egyrészt a nagy hőterhelés súlyos egészségügyi kockázatot jelent, másrészt komoly károkat okozhat az energiaellátásban, az infrastrukturális hálózatokban és az ökoszisztémákban, összességében csökkentve a lakosság jólétét (pl. Chapman et al., 2013; McGregor et al., 2015; Hatvani-Kovacs et al., 2018).

A regionálisan jelentkező HW időszakokban a mesterséges városi környezetben élő emberek jobban ki vannak téve az említett negatív hatásoknak, mind a vidéken, természetesebb környezetben élők, mivel a városok önmagukban is emelik a hőmérsékletet (városi hősziget, UHI). Ez elsősorban az esti-éjszakai órákban jelentkezik, rárakódva a hőhullám eleve magasabb értékeire, jelentősen emelve a minimum hőmérsékletet, akár olyan mértékben is, hogy hatása már világosan kimutatható a halálozási statisztikákban is (Haines et al., 2006; McGregor et al., 2015; Hatvani-Kovacs et al., 2018; Hintz et al., 2018; Kovats \& Hajat, 2008). Mivel mind a HW időszakok, mind pedig a hősziget erőteljes kifejlődéséhez elsősorban a nagyléptékü anticiklonális rendszerek kifejlődése a kedvező, eredőjükként akár annál is nagyobb városi hőterhelés is kialakulhat, mintha pusztán összegeznénk a HW és az UHI által okozott terhelést ( $\mathrm{Li} \&$ Bou-Zeid, 2013). Emellett, a települések szerkezetében, anyagában és az emberi aktivitásban lévő nagy heterogenitás miatt jelentős intra-urbán termikus különbségek jelenhetnek meg, kialakítva nagyobb (extrém), illetve kisebb hőterheléssel jellemezhető városrészeket (McGregor et al., 2015). Ezért fontos vizsgálni a HW időszakok városon belüli differenciált hatásait és ennek révén felderíteni azokat a városnegyedeket, ahol szélsőségessé válhat ekkor a hőterhelés, hogy itt az előzetes figyelmeztetésen kívül hangsúlyosabbak és erőteljesebbek lehessenek a terhelést csökkentő preventív akciók, mind a hatóságok, mind pedig az egyének részéről. E vizsgálatok mérési hálózatok, illetve lokális léptékủ modell-kimenetek adatain alapulhatnak.

A fentiekkel összhangban, e tanulmány célja a termikus komfort körülmények összehasonlítása egy erősen terhelő hőhullámos nyári időszak során regionális, illetve városi szinten. Hipotézisünk az, hogy a regionálisan kiadott/elörejelzett hőmérsékleti értékek jelentősen különbözhetnek a településre, főleg annak belterületére jellemző hőterhelés mértékétől. Ennek, az emberekre ható hőterhelésnek a kimutatására egy human 
bioklimatológiai mérőszámot, a Fiziológiailag Ekvivalens Hőmérsékletet (PET) használunk fel (Mayer \& Höppe, 1987), melynek eredeti hőérzeti/fiziológiai stressz kategóriáit (Matzarakis \& Mayer, 1996), korábbi eredményeink alapján, adaptáltuk a helyi lakossághoz (Kovács et al., 2016). Az alkalmazott adatbázist a szegedi városklíma monitoring hálózat biztosította (Unger et al., 2014; Gál \& Unger, 2016).

\section{Hőhullám - definíciók, mérőszámok}

Három HW definiciót alkalmazunk, hogy esettanulmányként kiválaszthassunk egy jellegzetes HW időszakot, Szeged környezetére vonatkozóan (1. táblázat). Az első definíció (HW1) általánosan alkalmazható, éghajlati zónától függetlenül, míg a második (HW2) csak hazánkra vonatkozik és a 2005-ben bevezetett hőségriasztási rendszer alapját jelenti. Saját javaslatunk (HW3) megköveteli mindkét napszak terhelő voltát.

\section{1. táblázat: A hőhullám és hőségriasztás néhány definíciója}

\begin{tabular}{|c|c|c|}
\hline Idöszak neve & Definíció & Hivatkozás \\
\hline HW1 & $\begin{array}{l}\text { tartam } \geq 5 \text { egymás utáni nap, amelyiken } T_{\max }>5^{\circ} \mathrm{C} \text { - } \\
\text { kal, mint az 1961-1990-ra vonatkozó napi } T_{\max } \text { érték }\end{array}$ & Frich et al. (2002) \\
\hline $\begin{array}{l}\text { HW2 } \\
\text { - Höségriasztás } 2 \\
\text { - Höségriasztás } 3\end{array}$ & $\begin{array}{l}\text { Magyarországon: } \\
\text { napi } T_{\text {attlag }}>25^{\circ} \mathrm{C} \text { (min. } 3 \text { egymás utáni nap) } \\
\text { napi } T_{\text {átlag }}>27^{\circ} \mathrm{C} \text { (min. } 3 \text { egymás utáni nap) }\end{array}$ & $\begin{array}{l}\text { Bobvos et al. } \\
\text { (2015), Pongrácz et } \\
\text { al. (2013) }\end{array}$ \\
\hline HW3 & $\begin{array}{l}\text { tartam } \geq 5 \text { egymás utáni nap, amelyiken } T_{\max } \geq 30^{\circ} \mathrm{C} \\
\text { (nyári nap), } T_{\min } \geq 20^{\circ} \mathrm{C} \text { (trópusi éjszaka) }\end{array}$ & jelen javaslat \\
\hline
\end{tabular}

Ez a három definíció (és még sok másik is) az adott régiót reprezentáló, településen kívül elhelyezkedő állomáson mért léghőmérséklet $(T)$ értékeire támaszkodik. Ezért, az innen kapott információ általában nem tükrözi maradéktalanul a városi lakosságot ért höterhelést, főleg nem egy HW időszak során (McGregor et al., 2015). Nevezetesen, az emberi test és környezete közötti hőcsere, illetve ennek eredményeként az emberi hőérzet nemcsak a $T$, hanem a légnedvesség és -áramlás, valamint a rövid- és hosszúhullámú sugárzás összhatásaként alakul ki. Ezt a kombinált hatást az emberi energiaegyenlegen alapuló modellek révén kapott különbözö bioklimatológiai indexekkel lehet közelíteni, ezért ezek sokkal reálisabban tükrözik az emberi höérzetet, mint a sima $T$ érték (pl. Höppe, 1993). Az egyik leggyakrabban alkalmazott ilyen index a Bevezetésben már említett PET.

\section{Vizsgált terület, adatok}

A 2014 óta müködő szegedi városklíma méröhálózat elemeit és a hálózat kialakításában szerepet játszó Lokális Klímazóna (LCZ) rendszer (Stewart \& Oke, 2012) itt előforduló típusait az 1. ábra szemlélteti. Jelen tanulmányban a D-1 állomás (LCZ D) adatai reprezentálják a városi hatástól mentes, a régióra jellemző körülményeket, míg a 2-1 állomás (LCZ 2) adatai a sürün beépített belvárosét (2. ábra). 


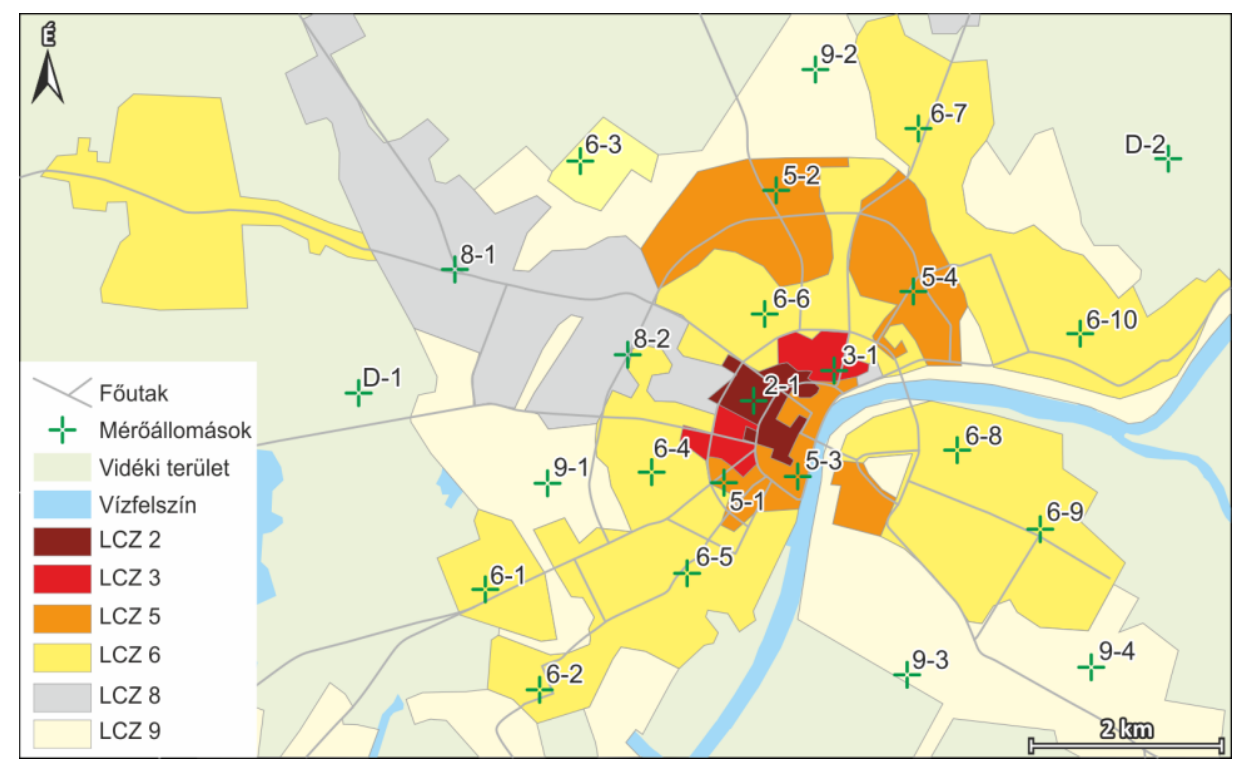

1. ábra: LCZ típusok térképe a városklíma mérőhálózat állomásaival Szegeden (számozás: első szám vagy betủ = LCZ típus; második szám = állomás sorszáma az adott zónában).

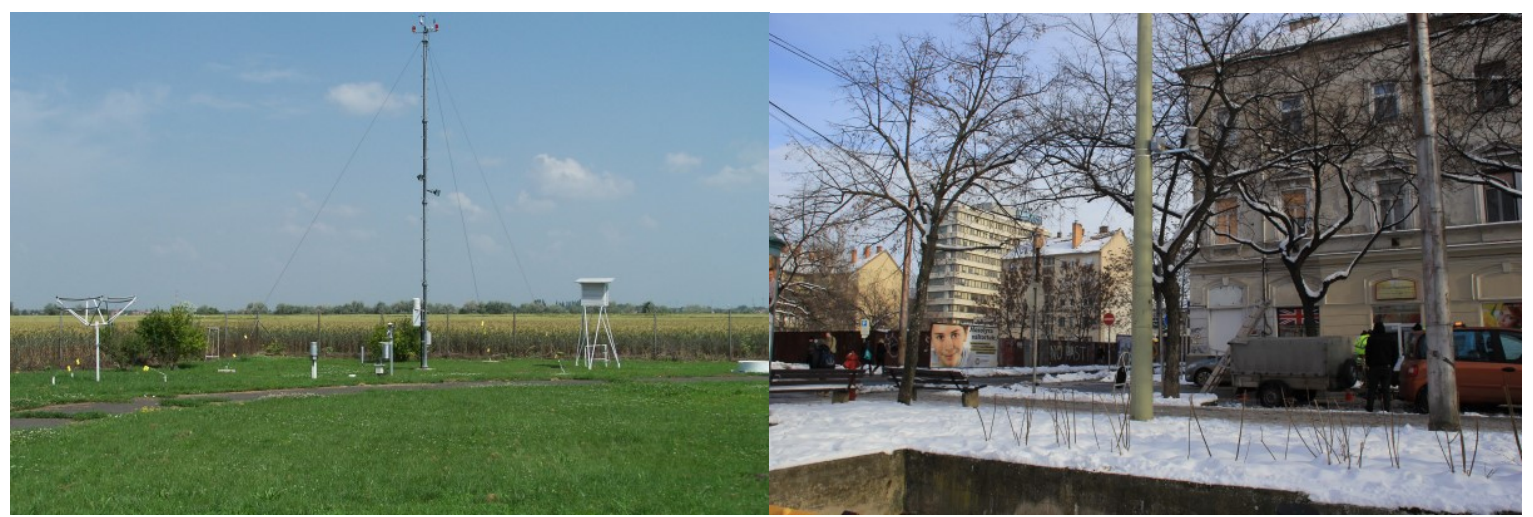

2. ábra: A külterületi D-1 állomás (balra) és a belvárosi 2-1 állomás (jobbra) fényképei.

A termikus komfort analízis során alkalmazott órás PET értékeket a RayMan modell segítségével számoltuk ki, melyhez a $T$, a relatív nedvesség $(R H)$, felhőborítottság $(C)$ és a szélsebesség $(u)$ értékei, valamint a hely koordinátái és a dátum szükségesek (Matzarakis et al. 2007, 2010). A vidéki D-1 állomás $T, R H, C$ és $u$ adatai közvetlenül az állomásról származnak. A belvárosi 2-1 állomás esetében a modellbemeneti adatok egyrészt az itt mért $T$ és $R H$ értékek, másrészt a felhőzeti információ ugyanaz, mint a D-1 nél, az $u$ kiszámítása pedig a D-1-en mért értékeken és a városi állomás körüli érdességi viszonyokon alapul (részletekért lásd Unger et al., 2015; Unger et al., 2018).

A PET eredeti és a helyi lakossághoz adaptált kategóriáit a 2. táblázat tartalmazza.

2. táblázat: Az eredeti, egész évre érvényes (*Matzarakis \& Mayer, 1996) és a helyi lakossághoz adaptált (**Kovács et al., 2016) nyári hőérzeti/fiziológiai stressz $\left(P E T,{ }^{\circ} \mathrm{C}\right)$ kategóriái.

\begin{tabular}{|c|c|c|l|c|c|c|l|}
\hline $\begin{array}{c}\text { Kategóriák } \\
\left(P E T,{ }^{\circ} C\right)\end{array}$ & hideg & hüvös & $\begin{array}{l}\text { enyhén } \\
\text { hüvös }\end{array}$ & neutrális & $\begin{array}{l}\text { enyhén } \\
\text { meleg }\end{array}$ & meleg & forró \\
\hline$* E$ Ev & $4-8$ & $8-13$ & $13-18$ & $18-23$ & $23-29$ & $29-35$ & $35-41$ \\
\hline$* *$ Nyár & n.a. & $-13,1$ & $13,1-17,3$ & $17,3-22,4$ & $22,4-28,9$ & $28,9-41,4$ & $41,4-$ \\
\hline
\end{tabular}




\section{Módszerek}

\subsection{A vizsgált időszak kiválasztásának szempontjai}

A 2014-2018 közötti öt nyár 15 hónapjából választottunk egy közel felhőmentes, 5 napos periódust, mint hőhullámos (HW) időszakot. A kiválasztás alapját a korábban említett definíciók képezték (1. táblázat), melyeket mind a napok hőmérsékleti értékeire, mind pedig ezek 5 napos átlagára is alkalmaztuk. A kiválasztás két kritériuma a következő volt:

(i) az időszak napjaira legalább egy teljesül a három HW-definícióból,

(ii) az időszak 5 napos átlagos $T$ értékei teljesítenek legalább kettőt a 3 definícióból.

A 30 éves referencia időszak átlagos értékeitől való eltérést nem az 1961-1990 időszakra, mint Frich et al. (2002) javasolja, hanem a közelebbi, 1981-2010 közötti időszakra vonatkoztattuk $\left(\mathrm{OMSz}^{1}\right)$.

Ezen kritériumok alapján a kiválasztott időszak 2017. július 30. és augusztus 3. közé esett. A 3. táblázat tartalmazza az időszak termikus jellemzőit és azt, hogy mennyiben teljesül valamelyik HW definíció. Az időszak közepső napjára vonatkozóan a napfelkelte időpontja 03:20-kor, míg a naplementéé 18:10-kor (UTC) volt.

3. táblázat: A kiválasztott időszak napi és 5 napos átlagos termikus jellemzői $\left({ }^{\circ} \mathrm{C}\right)(\mathrm{D}-1$ állomás adatai alapján). A + vagy - jelzi, hogy a napok, illetve a periódus teljesíti-e valamelyik HW definíciót.

\begin{tabular}{|c|c|c|c|c|c|c|c|c|}
\hline \multirow{2}{*}{\multicolumn{2}{|c|}{ dátum }} & \multicolumn{3}{|l|}{ napi } & \multirow{2}{*}{$\begin{array}{c}\text { anomália } \\
T_{\max } *\end{array}$} & \multirow[t]{2}{*}{$H W 1$} & \multirow[t]{2}{*}{$H W 2$} & \multirow[t]{2}{*}{$H W 3$} \\
\hline & & $T_{\text {átlag }}$ & $T_{\max }$ & $T_{\text {min }}$ & & & & \\
\hline \multirow{5}{*}{2017} & 07.30 & 24,2 & 33,4 & 15,0 & 4,6 & - & + & - \\
\hline & 07.31 & 26,9 & 33,1 & 20,7 & 3,1 & - & + & + \\
\hline & 08.01 & 28,3 & 36,1 & 20,5 & 6,3 & + & + & + \\
\hline & 08.02 & 28,1 & 37,0 & 19,1 & 7,5 & + & + & - \\
\hline & 08.03 & 29,0 & 38,0 & 20,0 & 7,6 & + & + & + \\
\hline \multicolumn{2}{|c|}{ 5-napos átlag } & 27,3 & 35,5 & 18,1 & 5,8 & + & + & - \\
\hline
\end{tabular}

*eltérés a HW1 definíciójához alkalmazott 1981-2010 normál időszak napi $T_{\max }$ értékétől (D-1 állomás, [1 - OMSZ])

\subsection{A HW idöszak jellemzése regionális és lokális megközelítéssel}

Először a régióra vonatkozó meteorológiai viszonyok napi változását elemeztük a vizsgált 5 napos időszak során, felhasználva a D-1 állomáson mért globálsugárzás $(G)$, léghőmérséklet $(T)$ és szélsebesség $(u)$ adatokat.

Második lépésként megvizsgáltuk, hogy egy ilyen extrém hőterhelést jelentő nyári periódusban milyen különbségek tapasztalhatók a régióra jellemző, a médiában (TV, rádió, internet, újságok) megjelenő aznapi, illetve előrejelzett termikus adatok (itt gyakorlatilag a $T$ ről van szó a hazai gyakorlatban) és a belvárosban élők által ténylegesen megtapasztalható, számszerüsített (PET) hőérzet között. Az összehasonlítást az teszi lehetővé és egyértelmüvé, hogy mindkét paraméternek ugyanaz $\left({ }^{\circ} \mathrm{C}\right)$ a mértékegysége. Felhasználva a paramétereknek a HW időszak 5 napjára vonatkozó órás átlagait, az összehasonlítás a külterületi és a belvárosi napi menetek és azok különbségeinek sajátosságain alapul.

\footnotetext{
${ }^{1}$ OMSz: Éghajlati adatsorok 1901-2010, Szeged.

http://met.hu/eghajlat/magyarorszag_eghajlata/eghajlati_adatsorok/
} 


\section{Eredmények és következtetések}

\subsection{Meteorológiai körülmények}

A 3. ábra a város körüli régióra vonatkozó meteorológiai viszonyok napi változását szemlélteti a vizsgált 5 napos időszak során.

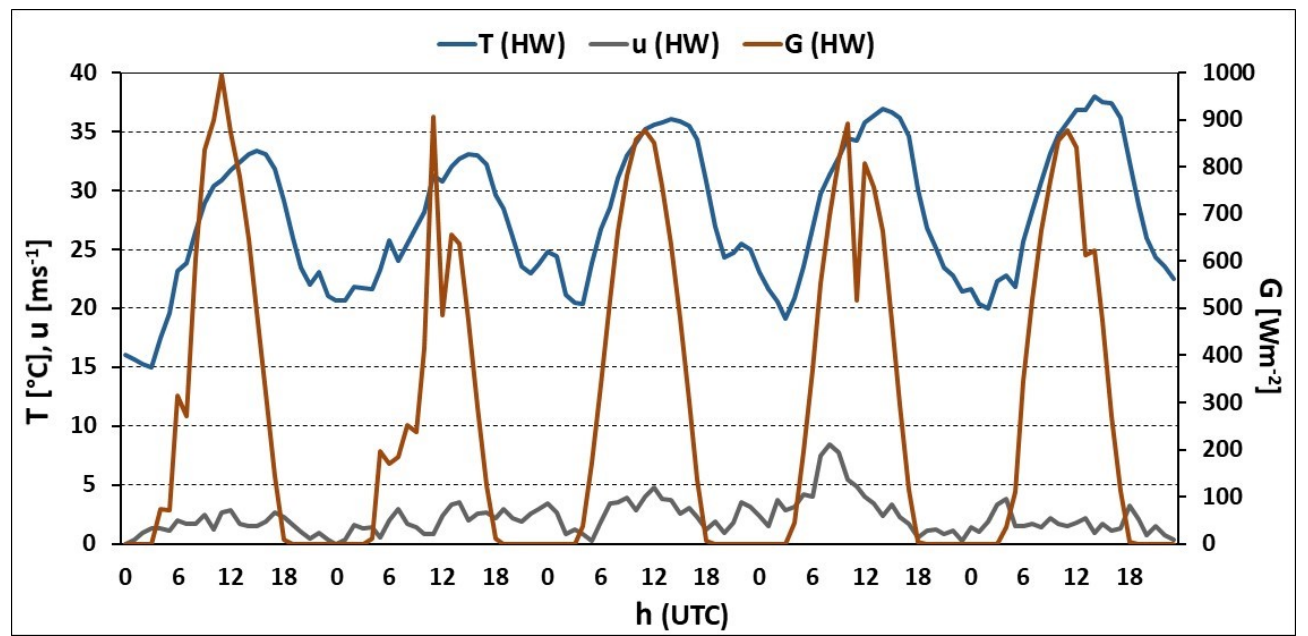

3. ábra: Hőmérséklet $(T)$, szélsebesség $(u)$ és a globálsugárzás $(G)$ napi menete a HW időszakban

(D-1 állomás adatai, 2017.07.30-08.03).

A besugárzás napi menetei a tipikus harang-görbe alakot követik, noha a nappal során időnként felhők módosítják ezt a szabályos alakot. A $T$ napról-napra emelkedő tendenciát mutat (33,1-38,0 ${ }^{\circ} \mathrm{C}$ közötti napi csúcsokkal), késő éjjel és hajnalban $20^{\circ} \mathrm{C}$ feletti értékekkel. A szél végig mérsékelt volt (tipikusan $0-3 \mathrm{~ms}^{-1}$ között), különösen éjszaka, csak néhány kiugró érték jelentkezett a nappali órákban a negyedik napon.

Összegezve, ezek a $G, T$ és $u$ adatok viszonylag tiszta és nyugodt időjárási körülményekre utalnak a vizsgált időszakban, vagyis kedvezőek voltak ahhoz, hogy az eltérő felszíni sajátosságok (vidék-belváros) mikro- és lokális léptékü klímahatásai érvényre juthassanak.

\subsection{A városi höérzet és a publikus hőmérséklet összehasonlitása}

Jelen fejezet azt tárgyalja, hogy egy hőhullámos időszakban a régióra megadott $(r, \mathrm{D}-1$ állomás) $T$ értékek mennyivel térnek el a vele egyidejüleg a városban tapasztalható, a $P E T$ révén számszerüsített belvárosi ( $u, 2-1$ állomás) hőérzettől. A régióra jellemző hőmérséklet és hőérzet, valamint a belvárosi hőérzet átlagos napi meneteit és azok eltéréseit a 4. és az 5. ábra mutatja be.

A 4. ábra alapján azonnal szembetűnik, hogy a nappali órákban a regionális $T$ igen nagymértékben alatta marad mind a bel-, mind pedig a külterületre vonatkozó $P E T$-nek, sőt a belvárosi $P E T$ gyakorlatilag a teljes 24 óra során a $T$ értékek felett marad, noha az estiéjszakai órákban az eltérés már nem olyan jelentős. 


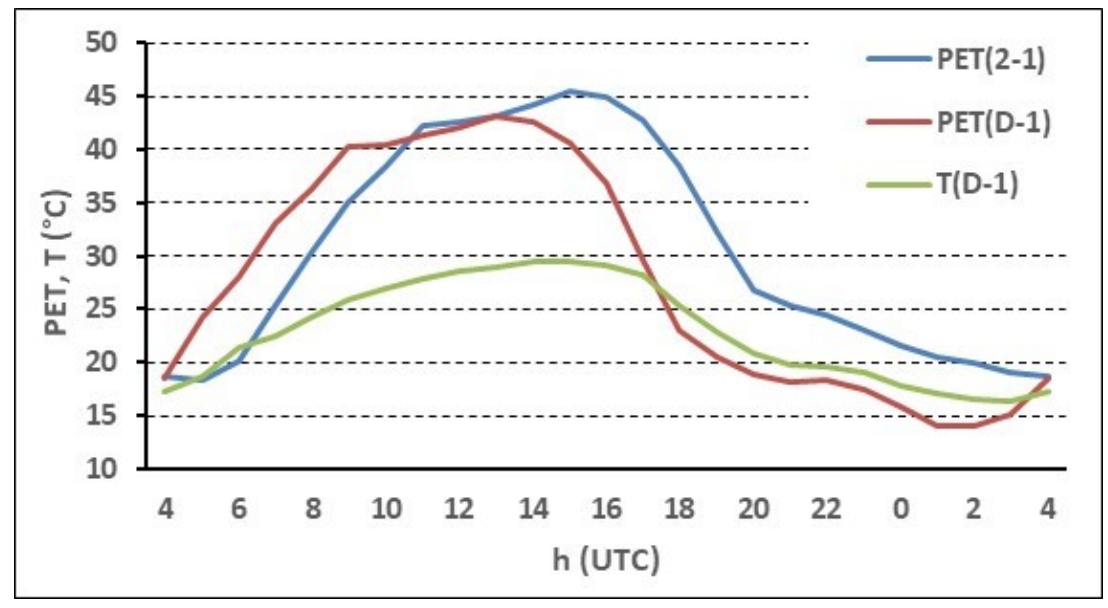

4. ábra: A regionális hőmérséklet $\left(T_{(D-1)}\right)$ és hőérzet $\left(P E T_{(D-1)}\right)$, valamint a belvárosi höérzet $\left(P E T_{(2-1)}\right)$ átlagos napi menete a HW időszakban (2017.07.30-08.03).

A nyílt külterület és a magasabb házakkal részben körbevett belvárosi helyen (2. ábra) a hőterhelés a nappali órákban nagyjából ugyanolyan mértékü, a maximumok közütti eltérés mindössze $2,2^{\circ} \mathrm{C}$ PET, mindkét helyen órákon át a "forró" höérzet (2. táblázat) dominál (1114 h és 11-17 h között a kül-, illetve belterületen). Jelentős különbség azonban, hogy ebben a nappali emelkedő-csökkenő ritmusban néhány órás időeltolódás tapasztalható, ugyanis a külterületen már hajnali 04 UTC-től megkezdődik a melegedés (napfelkelte - 03:20), míg a belvárosban csak két órával később. Ez megjelenik a maximumok bekövetkezésénél is (13 és $15 \mathrm{~h}$ ) és gyakorlatilag végig megmarad este $20 \mathrm{~h}$-ig. Jellemezö a termikus körülményekre, hogy a terhelö "meleg" vagy "forró" kategória uralkodik a külterületen már 06-07 h-tól 17 hig (hossza > 10 h), míg a belvárosban csak később kezdődik (08 UTC), de egészen 19 h-ig tart (hossza $>11 \mathrm{~h}$ ). Ez az időeltolódás alapvetően a két hely nyitottságával, illetve zártságával hozható összefüggésbe: a nyílt terület a napfelkelte után a besugárzás hatására rohamosan melegedni kezd (növekedés a PET értékekben), míg a belterületen ez a melegedés az épületek árnyékoló hatása miatt csak nagyobb napmagasságnál kezdődik meg. A nappal második szakaszában viszont a csökkenő napmagasság a nyílt helyen erőteljes lehülést indít meg (csökkenés a PET értékekben), amely csak a naplemente (18:10) után mérséklődik. Ezzel szemben a zártabb belvárosban a nap folyamán az épületek, utak, stb. besugárzás által elnyelt és részben elraktározódott hője fokozatosan bocsátódik ki, melegítve ezzel a környezetét, még jóval a naplemente utáni órákban is.

Az éjszaka folyamán a külterület $T$ és $P E T$ értékei között nincs jelentős különbség, a hőérzet a "neutrális" és "enyhén hủvös" kategóriában marad, míg a belvárosban a mesterséges felszín további hőkibocsátása következtében a PET értékek végig egy kategóriával feljebb maradnak.

Az 5. ábra amellett, hogy alátámasztja az előző megállapításokat, megkönnyíti a napi menetekben tapasztalható eltérések számszerüsítését. A bel- és külterület hőterhelése közötti különbség $\left(\triangle P E T_{u-r}\right)$ menetében világosan visszatükröződik az elözőekben említett időeltolódás: a délelőtti negatív értékek $\left(-7,9\right.$ és $-1,9{ }^{\circ} \mathrm{C}$ között), azaz a $P E T_{r}>P E T_{u}$, a korábban kezdődő melegedéssel van összhangban. A dél körüli órákban nincs jelentős különbség, majd 14 UTC-től kezdődően egészen hajnalig a $P E T_{u}>P E T_{r}\left(+1,7\right.$ és $+15,5^{\circ} \mathrm{C}$ között), szintén összhangban az előzőekkel. 


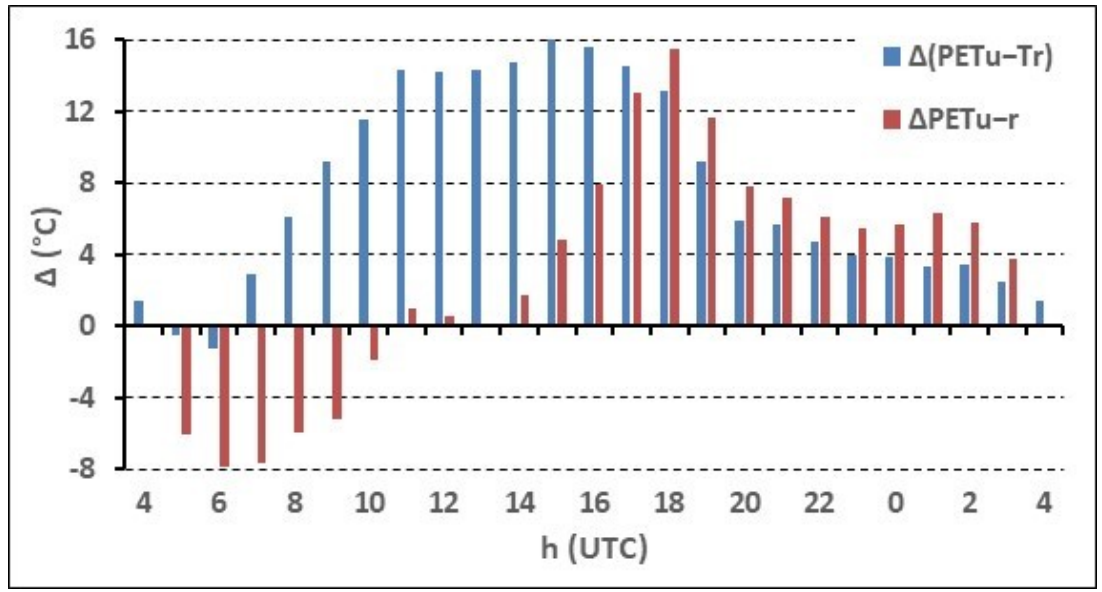

5. ábra: A belvárosi hőérzet eltérésének átlagos napi menete a regionális hömérséklettől $\left(\triangle\left(P E T_{u}-T_{r}\right)\right)$, valamint a regionális hőérzettől $\left(\triangle P E T_{u-r}\right)$ a HW időszakban.

Az igazán fontos, az eredeti hipotézisünket alátámasztó megállapításokat az 5. ábra kék oszlopai alapján lehet megtenni. A belvárosi $P E T$ és a külterületi $T$ közötti különbség $\left(\triangle\left(P E T_{u}-T_{r}\right)\right)$ napi menete alapján világosan megmutatkozik, hogy a médiában megjelenő, részben figyelmeztetésnek szánt információk mennyire félrevezetőek lehetnek a városban élők számára, hiszen a közölt $T$ értékek lényegesen alacsonyabbak, föleg a nappali órákban, mint amit a beépített terület lakói tapasztalhatnak. A $\Delta\left(P E T_{u}-T_{r}\right)$ a nappal jelentős részében meghaladja a $12{ }^{\circ} \mathrm{C}$-ot $(11-18 \mathrm{~h})$, maximuma pedig a $16^{\circ} \mathrm{C}$-ot $(15 \mathrm{~h})$, majd naplemente után az esti-éjszakai órákban a különbség mérséklődik $\left(0,1-9,2^{\circ} \mathrm{C}\right)$, de ekkor is többször meghaladja a $4{ }^{\circ} \mathrm{C}$-ot.

Elöző eredményeink alapján bevezethetö, mint új teminus, az ún. városi höterhelési többlet - $\Delta\left(P E T_{u}-T_{r}\right)$, amely a településeken élő emberek höterhelésének számszerüsítésére alkalmazott humán bioklimatológiai és az egyszerü, léghőmérsékleten alapuló megközelítések (és a kapcsolódó figyelmeztetések) eredményeinek különbségét adja meg.

Tehát, összegezve megállapítható, hogy a regionálisan kiadott/előrejelzett hőmérsékleti értékek jelentősen különbözhetnek a településre, föleg annak belterületére jellemző hőterhelés mértékétől, amely különbségeknek az extrém megterhelést jelentő hőhullámos időszakokban értékelődhet fel a jelentősége. Eredményeink felhívják a figyelmet arra, hogy az operatív előrejelzési gyakorlat során - főleg a nyári időszakban, illetve hőhullámok esetén - célszarü lenne a hőterhelést jellemző paraméter alkalmazása, így segítve a városi hatóságik és a lakosság felkészülését a várható valós hőterhelési viszonyokra.

\section{Köszönetnyilvánítás}

A kutatást az Emberi Erőforrások Minisztériuma támogatta (20391-3/2018/FEKUSTRAT).

\section{Hivatkozások}

Bobvos, J., Fazekas, B., Páldy, A., 2015: Assessment of heat-related mortality in Budapest from 2000 to 2010 by different indicators. Időjárás, 119: 143-158.

Chapman, L., Azevedo, J.A., Prieto-Lopez, T., 2013: Urban heat \& critical infrastructure networks: A viewpoint. Urban Clim., 3: 7-12. https://doi.org/10.1016/j.uclim.2013.04.001

Frich, P., Alexander, L.V., Della-Marta, P., Gleason, B., Haylock, M., Klein Tank, A.M.G., Peterson, T., 2002: Observed coherent changes in climatic extremes during the second half of the twentieth century. Clim. Res., 19: 193-212. https://doi.org/10.3354/cr019193 
Gál, T., Unger, J., 2016: Városklíma hálózat Szegeden. In: Kutatási és operatív feladatok meteorológusként. Az ELTE Meteorológus TDK 2016. évi Nyári Iskola elöadásának összefoglalói. (Pongrácz R., Mészáros R., Kis A. szerk.) Egyetemi Meteorológiai Füzetek, 27: 49-55. https://doi.org/10.31852/EMF.27.2016.049.055

Haines, A., Kovats, R.S., Campbell-Lendrum, D., Corvalan, C., 2006: Climate change and human health: impacts, vulnerability, and mitigation. Lancet, 367: 2101-2109. https://doi.org/10.1016/j.puhe.2006.01.002

Hatvani-Kovacs, G., Bush, J., Sharifi, E., Boland, J., 2018: Policy recommendations to increase urban heat stress resilience. Urban Clim., 25: 51-63.

https://doi.org/10.1016/j.uclim.2018.05.001

Hintz, M.J., Luederitz, C., Lang, D.J., von Wehrden, H., 2018: Facing the heat: A systematic literature review exploring the transferability of solutions to cope with urban heat waves. Urban Clim., 24: 714-727. https://doi.org/10.1016/j.uclim.2017.08.011

Höppe, P., 1993: Heat balance modelling. Experientia, 49: 741-746. https://doi.org/10.1007/BF01923542

Kovács, A., Unger, J., Gál, C.V., Kántor, N., 2016: Adjustment of the thermal component of two tourism climatological assessment tools using thermal perception and preference surveys from Hungary. Theor. Appl. Climatol., 125: 113-130. https://doi.org/10.1007/s00704-015-1488-9

Kovats, R.S., Hajat, S., 2008: Heat stress and public health: A critical review. Ann. Rev. Public Health, 29: 41-55. https://doi.org/10.1146/annurev.publhealth.29.020907.090843

Li, D., Bou-Zeid, E., 2013: Synergistic interactions between urban heat islands and heat waves: The impact in cities is larger than the sum of its parts. J. Appl. Meteorol. Climatol., 52: 2051-2064. https://doi.org/10.1175/JAMC-D-13-02.1

Matzarakis, A., Mayer, H., 1996: Another kind of environmental stress: thermal stress. WHO Newsletter, 18: 7-10.

Matzarakis, A., Rutz, F., Mayer, H., 2007: Modelling radiation fluxes in simple and complex environments - application of the RayMan model. Int. J. Biometeorol., 51: 323-334. https://doi.org/10.1007/s00484-006-0061-8

Matzarakis, A., Rutz, F., Mayer, H., 2010: Modelling radiation fluxes in simple and complex environments: basics of the RayMan model. Int. J. Biometeorol., 54: 131-139. https://doi.org/10.1007/s00484-009-0261-0

Mayer, H., Höppe, P., 1987: Thermal comfort of man in different urban environments. Theor. Appl. Climatol., 38: 43-49. https://doi.org/10.1007/BF00866252

McGregor, G.R., Bessemoulin, P., Ebi, K., Menne, B. (szerk.), 2015: Heatwaves and Health: Guidance on Warning-System Development. WMO-No. 1142, World Meteorological Organization - World Health Organization, ISBN 978-92-63-11142-5

Meehl, G.A., Tebaldi, C., 2004: More intense, more frequent, and longer lasting heat waves in the 21st century. Science, 305: 994-997. https://doi.org/10.1126/science.1098704

Pongrácz, R., Bartholy, J., Bartha, E.B., 2013: Analysis of projected changes in the occurrence of heat waves in Hungary. Adv. Geosci., 35: 115-122. https://doi.org/10.5194/adgeo-35-115-2013

Robinson, P.J., 2001: On the definition of a heat wave. J. Appl. Meteorol., 40: 762-775. https://doi.org/10.1175/1520-0450(2001)040<0762:OTDOAH>2.0.CO;2

Stewart, I.D., Oke, T.R., 2012: Local Climate Zones for urban temperature studies. Bull. Am. Meteorol. Soc., 93: 1879-1900. https://doi.org/10.1175/BAMS-D-11-00019.1

Unger, J., Savić, S., Gál, T., Milosević, D., 2014: Urban climate and monitoring network system in Central European cities. Novi Sad (ISBN:987-86-7031-341-5), 101p 
Unger, J., Gál, T., Csépe, Z., Lelovics, E., Gulyás, Á., 2015: Development, data processing and preliminary results of an urban human comfort monitoring and information system. Időjárás, 119: 337-354.

Unger, J., Skarbit, N., Gál, T., 2018: Evaluation of outdoor human thermal sensation of local climate zones based on long-term database. Int. J. Biometeorol., 62: 183-193.

https://doi.org/10.1007/s00484-017-1440-Z

\section{Internetes hivatkozások}

OMSz: Éghajlati adatsorok 1901-2010, Szeged.

http://met.hu/eghajlat/magyarorszag_eghajlata/eghajlati_adatsorok/

\section{ORCID}

Unger J. (D) https://orcid.org/0000-0002-0637-0091

Gál T. ID http://orcid.org/0000-0002-1761-3239 